\title{
FRACTURE SYSTEMS IN DEVONIAN SANDSTONES, SOUTH ESTONIA
}

\author{
Anne KLEESMENT ${ }^{\mathrm{a}}$ and Enn PIRRUS ${ }^{\mathrm{b}}$
}

a Institute of Geology, Tallinn Technical University, Estonia pst. 7, 10143 Tallinn, Estonia; kleesmen@gi.ee

${ }^{b}$ Mining Institute of Tallinn Technical University, Kopli 82, 10412 Tallinn, Estonia; pirrus@staff.ttu.ee

Received 3 April 2000, in revised form 25 May 2000

\begin{abstract}
The results of recent field observations of fracturing in Middle Devonian sandstones outcropping in South Estonia are presented. Fractures in the rocks are mainly vertical, planar, usually cross-cutting the entire outcrop within an observable vertical reach of up to $10 \mathrm{~m}$. Fractures in horizontal direction can occur in caves as $5-15 \mathrm{~m}$ long linear stretches. In outcrops some fissures can be seen within a horizontal reach of up to $40 \mathrm{~m}$. The frequency of fractures is variable, the predominant distance between them is $10-20 \mathrm{~m}$. A denser fracture net is characteristic of the upper part of the studied section. The orientation of the fractures determined by 235 measurements shows the existence of two diagonal sets, the one in NE-SW direction being more expressive. Orientationof fracturing differs a little in different stratigraphical units. Main directions and features of fracturing agree with widespread planetary fracturing.
\end{abstract}

Key words: tectonics, fracturing, sandstones, Devonian, Estonia.

\section{INTRODUCTION}

Fracturing of the North Estonian Ordovician and Silurian limestone platform rocks is comparatively well studied (Heinsalu \& Andra 1975). For several reasons little is known about the fractures in Devonian sandstones outcropping in South Estonia. First, fracturing of hard carbonate rocks is very dense, systematic, and expressive. In poorly lithified, porous, and soft Devonian sandstones the stress development is largely compensated by shifts taking place between the particles in the pore section, and therefore fracturing of these rocks can never be very attractive. That is also why fracturing of sandstones has not been much dealt with worldwide (Sirat 1999). Second, the outcropping of Devonian sandstones is modest, occurring mainly on steep slopes of river valleys cut deep into the bedrock and on shores of large lakes. Third, the priority level of the problem is different in different parts of Estonian territory. In North Estonia the study of karst phenomena and ground water resources or hydrogeological management of 
oil-shale mining are inconceivable without monitoring the fracturing. In South Estonia such stimulating practical applications are almost non-existent. However, in the past few years the data on the fracturing of Devonian rocks have proved essential. Several expressive fissures have been found, for example, in Piusa sand quarry (Sõstra 1997) and presumably also near the fen massive of Meenikunno (Heinsalu et al. 1992). Water circulation in sandstone fractures is becoming more and more important in the hydrogeological management of South Estonia because there exists direct connection between springs opening in river valleys and the fractures in sandstones, as well as numerous caves, suffosional at first, later often distorted by human hands. The direction of the river valleys is often congruent with the orientation of fractures (Miidel 1966, 1971, 1982; Baeva 1978). Thus, the fracturing of Devonian sandstones of South Estonia is becoming a key problem in the geology of this region, and any preliminary information about it could be extremely useful for further research.

The authors have a remarkable collection of observation data, both about the orientation of fracture systems in Devonian sandstones and the spacing of fractures. During the compilation of the Book of Primeval Nature of Estonia in 1994-99, for nature protection purposes in the southern counties (Pärnu, Viljandi, Valga, Võru, Põlva, and Tartu) all major Devonian outcrops and caves were studied, paying great attention to the occurrence of fractures. Altogether, 206 Middle Devonian outcrops of the Aruküla, Burtnieki, Gauja, and Amata formations and caves in them were investigated and 235 fractures were documented (Fig. 1).

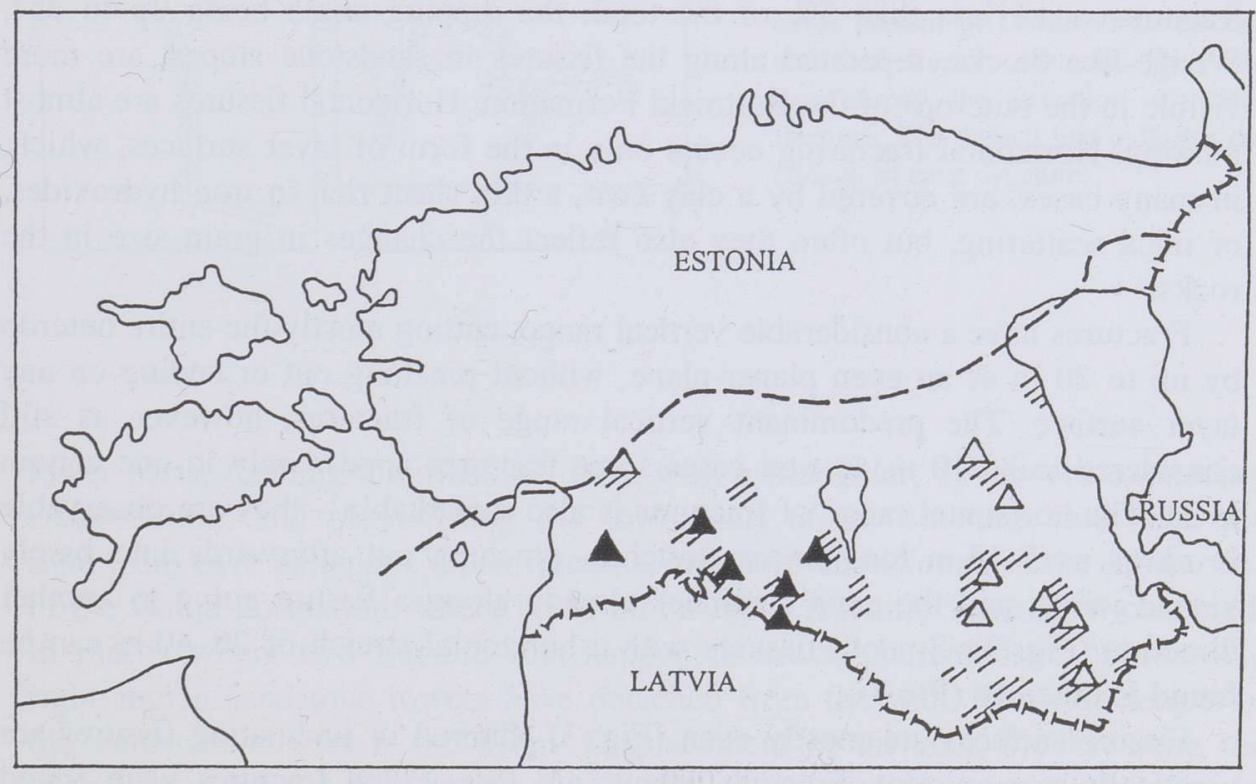

$\triangle 1$

$\triangle 2$

$1 / 13$

Fig. 1. Sketch-map of the main Devonian outcrops in Estonia. 1, cave; 2, cave with a clearly visible fracture net; 3 , major outcrop areas. The fragmentary line shows the northern limit of the distribution of Devonian rocks. 


\section{MATERIAL AND METHODS}

The observation and measurement data were collected mainly by the authors. The orientation of fractures in outcrops was measured with the geologist's compass on reliable surfaces. Additional data were obtained by drawing the cave plans and analysis of the already existing plans. Measurement results from field notebooks of earlier researchers (H. Viiding, Ü. Heinsalu) make no more than $5 \%$ of the total data. The spacing of the fractures was examined in a few bigger sandstone scarps (Kallaste cliff, Tartu cemetery outcrop). In order to draw general conclusions, somewhat more remote calculations and estimations were made.

The morphology of fissures was not investigated in detail. The features observed in the outcrops were rather variable, ranging from joints to open fractures widened in suffosion. Fissures in cave systems often proved to be damaged by later diggings, and thus only their general orientation could be established.

\section{RESULTS}

\section{The character of the fractures}

Fracturing in Devonian sandstones is mainly vertical to subvertical. Dipped fractures make less than $5 \%$ of the total, the dipping angle being up to $35^{\circ}$. Wedge-like blocks, separated along the fissures in sandstone slopes, are more visible in the outcrops of the Burtnieki Formation. Horizontal fissures are almost missing. Horizontal fracturing occurs only in the form of layer surfaces, which, in many cases, are covered by a clay coat, a thin sheet rich in iron hydroxides, or mica scattering, but often they also reflect the changes in grain size in the rocks.

Fractures have a considerable vertical range, cutting mostly the entire outcrop by up to $20 \mathrm{~m}$ as an even planer-plane, without pinching out or ending on any layer surface. The predominant vertical range of fractures, however, is still considered to be $10 \mathrm{~m}$. In rare cases some fractures appear only in one certain level. The horizontal range of fractures is also remarkable - they are observable in caves as $5-15 \mathrm{~m}$ long linear stretches, pinching out afterwards into barely visible joints, and the cave continues already along a fissure going to another direction (Fig. 2). Smooth fissures with a horizontal stretch of $20-40 \mathrm{~m}$ can be found in outcrops (Fig 3).

Fissure surfaces are mostly even (Fig. 3). Curved or undulating fissures are practically non-existent. Fracture fillings are rare. Filled fractures were found only in the fracture system of Piusa quarry, where beds of the Gauja Formation are exposed (Sõstra 1997). Elsewhere joints have partly been widened due to the water running through them. Water widens fractures noticeably in their 

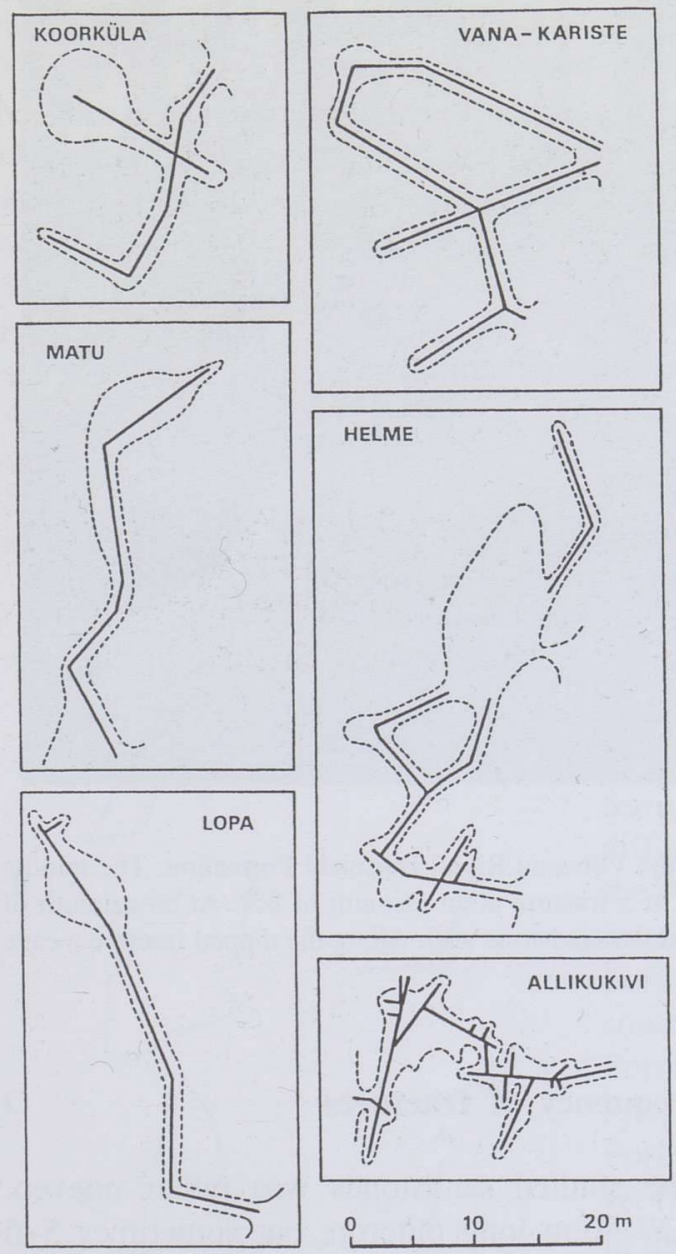

Fig. 2. Main schemes of some longer caves present in Devonian sandstones and their fracture systems. The solid line shows the direction of clear fractures. The dashed line indicates the contour of cave structures.

lower parts, forming a suffosional cave with a triangular, downward expanding cross-section, and often filling the lower part of the fracture void with the sand from cave collapses. Open fractures are more often found in the sandstones of the Gauja Formation, where up to $20 \mathrm{~cm}$ wide fractures have been observed. In places where two fracture sets happen to cross, characteristic column-like right-angled sandstone towers have detached from the wall. The side length of the sandstone towers is $0.5-10 \mathrm{~m}$. Displacement of the rock blocks along the fissure was noticed only in the upper part of the studied cross-section, in the sandstones of the Gauja and Amata formations. In the case of displacement we may be dealing with the detachment of a rock block from the massive, due to the gravitational force in valley slopes. 


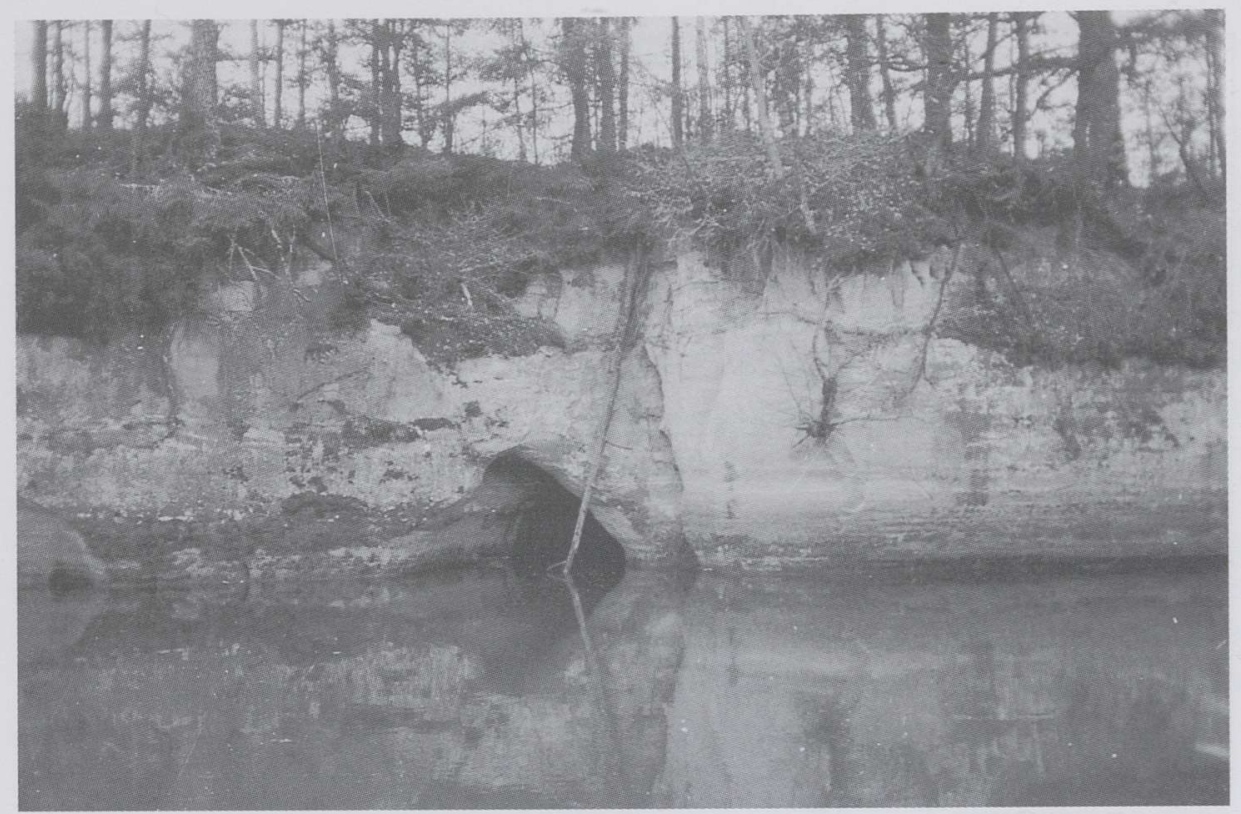

Fig. 3. Punnküla outcrop on the right side of the Võhandu River, Burtnieki Formation. The middle $40 \mathrm{~m}$ of it is orientated along the even plane of a fracture at an azimuth of $80^{\circ}$. At an azimuth of $195^{\circ}$ a horizontal and a dipped fracture cut into the sandstone wall. Along the dipped fracture a cave structure is formed. Photo by E. Pirrus 1999.

\section{Spacing and frequency of fractures}

The placement of fractures in the studied sandstones was rather uneven. Mostly 2-4 fractures occurred in a 20-40 m long outcrop, but sometimes 5-6 fractures could lie side by side at a distance of $10-20 \mathrm{~cm}$ from each other, whereas the next fracture was found 40-60 m away. In several cases, just 1-3 fractures could be found in a 100-120 m long sandstone scarp. At the same time, 5 fractures crossed at different intervals the $17 \mathrm{~m}$ long principal axis of the Allikukivi cave (Fig. 2). The predominant distance between the fractures was 5-15 m, in sandstones of the Aruküla Formation most likely even more, 30-50 m, in some cases up to $100 \mathrm{~m}$ (Kallaste cliff). Hence, the fractures in Devonian sandstones may divide the solid rock into blocks of various sizes. The size of the blocks may reach $100 \mathrm{~m}$. The fracture pattern appeared to be considerably denser in sandstones of the Gauja and Amata formations.

\section{Orientation of fractures}

The most valuable information comes from the statistical analysis of fracture orientation. In spite of the apparent lack of a distinct fracture system in separate 
outcrops, the rose diagram compiled on the basis of all measurements shows two clear conjugate sets of vertical fractures intersecting at $80^{\circ}$. The stronger set has the N-NE azimuth of $300^{\circ}$ (Fig. 4D). Therefore we may conclude that the fracturing in Devonian sandstones is far from being an incidental process, but it is clearly subjected to general planetary stress fields, reflecting as a whole the prevailing diagonal direction observable throughout the geological time (Shul'ts 1965, 1973, 1976; Bjerkeus et al. 1994). Other authors have also determined similar orientation of fracture zones in poorly lithified sediments in northeastern Europe. The prevailing fault directions in the Early Devonian of Spitzbergen are $143^{\circ}$ and $68^{\circ}$ (Friend et al. 1997); the first direction more or less coincides with our estimations, but the other has an eastward shift. The principal NE-SW and NW-SE orientation of the fracture systems has been recorded in the Middle Devonian of Great Britain (Edwards et al. 1997).

A

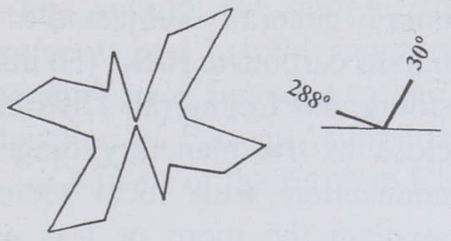

B

C

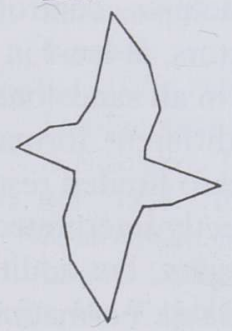

D
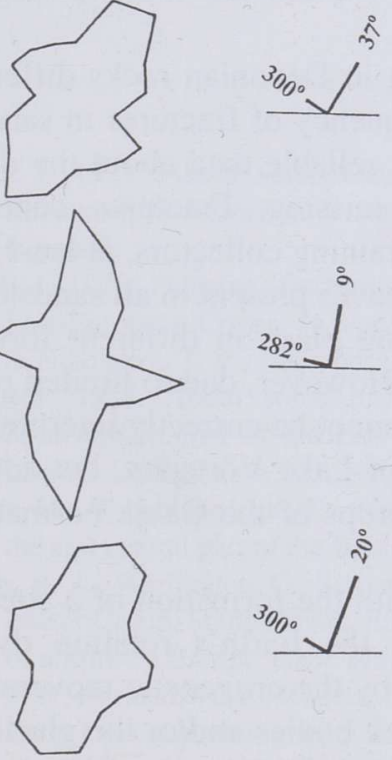

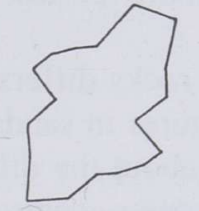

Fig. 4. Rose diagrams (left) and vector diagrams (right) of orientation of fractures in Devonian sandstones of Estonia. (A) Amata and Gauja formations, 28 measurements; (B) Burtnieki Formation, 90 measurements; (C) Aruküla Formation, 117 measurements; (D) all 235 measurements.

Interesting changes take place in the orientation of fracturing in different formations. Leaving aside the results of 28 measurements of the uppermost sand complex of the Gauja and Amata formations (Fig. 4A), we can note clear difference between the outcrop areas of the Aruküla Formation (Fig. 4C) opening in the north and of the Burtnieki Formation (Fig. 4B) spreading in the south. The rose diagram of the Burtnieki Formation is close to an ideal diagonal system $\left(315-45^{\circ}\right)$; that of the Aruküla Formation resembles more an orthogonal set $\left(270-0^{\circ}\right)$. This is especially well seen in the vector diagrams (Fig. 4, right). The difference between the fracture systems is probably not accidental and can hardly be explained by the change of planetary stress fields affecting the fracturing during the period between Aruküla and Burtnieki ages, because most likely the fracturing took place in post-Devonian times, when the entire complex under study was wholly hardened and buried.

Previous measurement data from the sandstones of the upper part of the Burtnieki Formation in the Võhandu River valley have given the fracturing maximum at an azimuth of $50^{\circ}$ (Miidel 1982). Data from the Burtnieki and 
Gauja formations on Latvian territory have yielded a fracturing maximum of 315-65 , which in NE direction tilted a little eastward from the ideal diagonal direction (Baeva 1973, 1978). However, the NE direction of fracturing is dominant only in East Latvia; due east, fracturing is orientated SW $\left(315^{\circ}\right)$. The SW orientation characterizes the whole region (Baeva 1976; Smirnov 1976) as well as the largest fault structures in the region of the Baltic aquatorium (Bjerkéus et al. 1994). Different directions of fractures are most likely caused by as yet unknown stress of different stratigraphical levels. It is possible that the lithological peculiarities of the complexes have some part in it, as has the placement of rock outcrops in the stress fields, influenced by different macrostructures.

\section{CONCLUSIONS}

The fracturing in Devonian sandstones of Estonia is generally subjected to the same rules that can be observed in North Estonian hard carbonate rocks (Heinsalu \& Andra 1975). In carbonate rocks of North Estonia and Leningrad District of Russia, two main directions of fractures are close to the planetary diagonal fracturing (Shul'ts 1965, 1973, 1976). The connection with local tectonic structures is not visible, nor would the latter explain the more or less even distribution of fracturing on the studied territory.

Due to lithological differences the fracturing in Devonian rocks differs from that in North Estonian carbonate rocks. The frequency of fractures in sandstones is considerably lower. Fracture fillings are rare, reliable data about the different age of fractures of different directions are missing. Fractures control the movement of ground water in rocks, being the draining collectors, at least in their emerging zones, and occurring as lineaments in caves present in all sandstones.

Changes in the orientation of fractures taking place in different formations deserve more attention in the following studies. However, due to limited research possibilities because of the bad exposure, they cannot be correctly interpreted yet. Further studies are necessary on the area west of Lake Võrtsjärv, but additional measurements of fracture directions on the outcrops of the Gauja Formation are needed as well.

The appearance of fracturing is connected with the formation of a stress field in the sedimentary complex, whether due to the Earth's rotation dynamics (Shul'ts 1965, 1973, 1976), stress fields caused by the orogenetic movements, or even because of the pressure of the covering rock bodies and/or the glacier mass (Sirat 1999). Fracture systems of different directions do not usually originate simultaneously, but they are the result of several subsequent events, which is confirmed by the analysis of fracture filling observable in North Estonian carbonate rocks (Möls 1961; Heinsalu \& Andra 1975; Niin et al. 1981). Important movements causing stresses in the rock complexes are assumed to have taken place in the northwestern part of Europe in the Late Devonian and in the Middle Permian (Edwards et al. 1997), but after certain intervals these processes continued up to the Paleogene (Friend et al. 1997). 
It is possible that beside large-scale regional tectonic movements the HaanjaLokno Uplift, which is still continuously rising on the northern slope of the Mõniste antecline (Sildvee \& Vaher 1995), has played a certain role in the fracturing. This possibility has been considered also in the corresponding studies of the Upper Devonian carbonate rocks in the surroundings of Irboska (Shul'ts 1965).

The above data are not sufficient to answer the numerous questions about the formation and nature of fractions. Nevertheless, the authors hope that the present work gives a certain outline for further studies.

\section{ACKNOWLEDGEMENTS}

The authors are grateful to R. Vaher, A. Miidel, and V. Puura for critical comments and helpful suggestions and to $\mathrm{H}$. Pohl for linguistic improvements. The study was financed by the research project No. 0140226 of the Ministry of Education of Estonia "Lithological and mineralogical preconditions for rational use of bowels of the Earth in Estonia".

\section{REFERENCES}

Baeva, R. I. 1973. About some features of planetary fracture systems in Latvian rocks. In Planetarnaya treshchinovatost' (Shul'ts, S. S., ed.), pp. 138-144. Leningradskij Univ. (in Russian).

Baeva, R. I. 1976. Planetary fracturing and tectonic dislocations in the northwestern part of the East-European Craton. In Voprosy izucheniya planetarnoj treshchinovatosti (Shul'ts, S. S. \& Nikolaeva, T. V., eds.), pp. 17-21. Geogr. o-vo SSSR, Leningrad (in Russian).

Baeva, R. I. 1978. About some features of the distribution of planetary fracturing in the northwestern part of the East-European Craton and its appearance in relief. Uch. Zap. Leningradskogo univ., ser. geografiya, 26, 96-108 (in Russian).

Bjerkéus, M., Gelumbauskaite, Z., Sturkell, E., Floden, T. \& Grigelis, A. 1994. Paleochannels in the east central part of the Baltic Proper. Baltica, 8, 15-26.

Edwards, R. A., Warrington, G., Scrivener, R. C., Jones, N. S., Haslam, H. W. \& Ault, L. 1997. The Exeter Group, South Devon, England: a contribution to the early post-Variscian stratigraphy of northwest Europe. Geol. Mag., 134, 177-197.

Friend, P. F., Harland, W. B., Rogers, D. A., Snape, I. \& Thornley, R. S. W. 1997. Late Silurian and Early Devonian stratigraphy and probable strike-slip tectonics in northwestern Spitsbergen. Geol. Mag., 134, 459-479.

Heinsalu, Ü. \& Andra, H. 1975. Jointing in Oil-Shale Basin and Geophysical Research Methods for its Study. Valgus, Tallinn (in Russian).

Heinsalu, Ü., Pirrus, E. \& Tiirmaa, R. 1992. Kas lõhe raba all? Eesti Loodus, 12, 268-269.

Miidel, A. 1966. On the connection of the directions of the Estonian valleys with the directions of tectonic joints. In Eesti Geograafia Seltsi Aastaraamat 1964/1965, pp. 18-33. Valgus, Tallinn (in Russian).

Miidel, A. 1971. New data on the interdependence of the directions of the North-Estonian valleys and tectonic joints. ENSV TA Toim. Keemia. Geol., 20, 158-162 (in Russian). 
Miidel, A. 1982. On the interdependence between the fracturing of the Devonian rocks and the direction of the middle course of the Võhandu River valley (South Estonia). ENSV TA Toim. Geol., 31, 80 (in Russian).

Möls, E. 1961. Eesti aluspõhja lõhede geneesist. In Geoloogiline kogumik (Orviku, K., ed.), pp. 5-15. LUS, Tartu.

Niin, M., Niin, S., Puura, V. \& Taalmann, V. 1981. Lõhetäidetest Tallinna ümbruse paemurdudes. In Settekivimid ja tektoonika (Pirrus, E., ed.), pp. 113-125. LUS, Tallinn.

Shul'ts, S. S. 1965. Planetary jointing and orientation of some linear forms of relief. In Osnovnye problemy izucheniya chetvertichnogo perioda, pp. 147-150. Nauka, Moscow (in Russian).

Shul'ts, S. S. 1973. Planetary fracturing (the fundamental concept). In Planetarnaya treshchinovatost' (Shul'ts, S. S., ed.), pp. 5-37. Leningradskij univ. (in Russian).

Shul'ts, S. S. 1976. The modern aspects of planetary fracturing and further tasks of their exploration. In Voprosy izucheniya planetarnoj treshchinovatosti (Shul'ts, S. S. \& Nikolaeva, T. V., eds.), pp. 4-8. Geogr. o-vo SSSR, Leningrad (in Russian).

Sildvee, H. \& Vaher, R. 1995. Geologic structure and seismicity of Estonia. Proc. Estonian Acad. Sci. Geol., 44, 15-25.

Sirat, M. 1999. Structural and neural network analyses of fracture systems at the Äspö Hard Rock Laboratory, SE Sweden, Uppsala. Acta Univ. Upsaliensis, 20.

Smirnov, V. M. 1976. The planetary fracturing of Paleozoic sedimentary rocks of Central Baltic area and its reflection in lineaments. In Voprosy izucheniya planetarnoj treshchinovatosti (Shul'ts, S. S. \& Nikolaeva, T. V., eds.), pp. 40-44. Geogr. o-vo SSSR, Leningrad (in Russian).

Sõstra, Ü. 1997. Tektoonilised makoorerikked Piusa karjääris. Eesti Loodus, 6, 268-269.

\title{
EESTI DEVONI LIIVAKIVIDE LÕHELISUS
}

\section{Anne KLEESMENT ja Enn PIRRUS}

On toodud andmed Lõuna-Eestis avanevate keskdevoni liivakivide lõhelisuse kohta. Lõhed on neis kivimeis harilikult vertikaalsed ja tasapinnalised, enamikul juhtudel kogu paljandiseina läbivad. Horisontaalsuunas on lõhed mööda paljandiseina jälgitavad kuni $40 \mathrm{~m}$, vertikaalsuunas kuni $10 \mathrm{~m}$ ja koobastes $5-15 \mathrm{~m}$ pikkuste sirgjooneliste lõikudena. Lõhede esinemissagedus on muutlik, tavapäraseim vahekaugus on 10-20 m. Lõhede orientatsioon 235 mõõtmistulemuse põhjal näitab kahe diagonaalse süsteemi olemasolu; tugevamini avaldub kirde-edela suund. Eri stratigraafilistes üksustes on lõhede orienteeritus mõnevõrra erinev. Lõhelisuse tüüp vastab globaalselt levivale nn. planetaarsele (üldisele) lõhelisusele.

\section{ТРЕЩИНОВАТОСТЬ ДЕВОНСКИХ ПЕСЧАНИКОВ ЭСТОНИИ}

\author{
Анне КЛЕЕСМЕНТ и Энн ПИРРУС
}

Представлены данные о трещиноватости среднедевонских песчаных обнажений в Южной Эстонии. Трещины преимущественно вертикальные и гладкостенные. Их протяженность по горизонтали достигает 40 м (по 
прямолинейным участкам пешер - 5-15 м), по вертикали редко превышает 10 м. Плотность трещиноватости изменчива, но чаще встречаются трещины через 10-20 м. В ориентации трещин выделяются две диагональные системы, из них сильнее выражена северо-восточная-юго-западная. Наблюдаются некоторые особенности трещиноватости в различных стратиграфических подразделениях. Трещиноватость песчаников соответствует широкоразвитой планетарной (общей) трещиноватости. 